\title{
MODELING OF CRITICAL PROFITABILITY FACTORS: EMPIRICAL RESEARCH FROM FOOD INDUSTRY IN SERBIA
}

\author{
Jelena Tadić ${ }^{1}$, Jelena Jevtić ${ }^{2}$, Nikola Jančev ${ }^{3}$ \\ *Corresponding author E-mail: jevticj.vts@gmail.com
}

\begin{abstract}
A R T I C LE IN F O
A B S T R A C T

Original Article

Received: 20 May 2019

Accepted: 04 June 2019

doi:10.5937/ekoPolj1902411T

UDC 658.155[168.52:663/.664(497.11)

Keywords:

Profitability, critical success

factors, food industry

JEL: D22, L25, L66

The paper is motivated by practical and always current problem of increasing profitability as one of the organizational performances. Critical success factors (CSFs) answer the question about what drives growth, profitability, and success in company. The research presented in this paper was conducted on a sample of two hundred companies in the food industry of the Republic of Serbia. The aim of the research is whether and to what extent there is a link between the assumed critical success factors and profitability, as well as determining the contribution of critical factors to predicting profitability. Based on techniques of correlation and multiple regression analysis, it was found that the efficiency, innovation, quality and flexibility, as critical factors explain a statistically significant part of the variance in profitability reflected by indicators ROA, ROE and EBITDA margin.
\end{abstract}

(C) 2019 EA. All rights reserved.

\section{Introduction}

The importance of the food industry, as a sub-sector of the processing industry, is remarkable for the domestic economy. As one of the most important sectors of the economy, in 2017, the processing industry accounted for 15.1 percent of the gross domestic product of the Republic of Serbia, while the real growth rate of the manufacturing industry amounted to 4.8 percent (Statistical Office of the Republic of Serbia, 2018, p. 141). The food industry provides employment for 84.589 people and participates in total employment with 4.3 percent in 2017 (Statistical Office of the Republic of Serbia, 2018, p. 74). In 2017, the production of food products accounted for 10.3 percent of total exports of the Republic of Serbia (Statistical Office of the

1 Jelena Tadić, PhD, Tadex Advisory, Simeona Pišćevića 11/1, +38162540487, ajelena83@ gmail.com https://orcid.org/0000-0003-1369-6329

2 Jelena Jevtić, MSc, Higher Medical and Business-Technological School of Applied Studies in Šabac, Hajduk Veljkova 10, Šabac, Serbia, +381649858608, jevticj.vts@gmail.com, https://orcid.org/0000-0003-3537-657X

3 Nikola Jančev, PhD, Higher Medical and Business-Technological School of Applied Studies in Šabac, Hajduk Veljkova 10, Šabac, Serbia, +381653324282, jancevn@gmail. com, https://orcid.org/0000-0003-1280-9184 
Republic of Serbia, 2018, p. 309). In this way, the food industry is the lifeline of the national economy and the basis for conducting research.

Taking into account that one of the main objectives of every company is profitability (Pervan, M., Mlikota, M., 2013; Vuković, B., Jakšić, D., 2019), it is obvious why critical success factors (CSFs) model as determinant of companies' profitability have attracted the interest of academic research . There are many things going on daily that sometimes managers lose their sight on important things and on factors that can have influence on the bottom line. That is why critical success factors model comes into play in the strategic analysis of the organization (Alias, Z. et al., 2014; Kotula, M. et al., 2015). Critical success factors answer the question about what drives growth, profitability, and success in company. It is important for managers to understand the dynamics of the factors that drive profitability, and growth to take advantage of them to improve their competitive position. Critical success factors as any other strategic model is iterative and dynamic, managers who can use strategic models dynamically, creatively, and competitively will achieve superior performance.

The aim of the research is to investigate whether there is a link between the assumed critical factors and profitability, as well as determining the contribution of critical factors to predicting profitability expressed by return on assets (ROA), return on equity (ROE) and earnings before interest, taxes, depreciation and amortization (EBITDA) divided by total revenue (EBITDA margin).

\section{Literature review}

Profitability is the primary goal of all business ventures. Profitability indicates the earning power and business success of a company (Kimmel, P. et al., 2012). A business that is not profitable cannot survive. Conversely, highly profitable business has the ability to reward its owners with a large return on their investment. Measuring profitability is the most important measure of the success of the business. Many researches have shown that there are different methods that can be used to measure profitability. The two most common measurements for profitability appears to be return on assets - ROA (Barton, S.L., Gordon, P.J., 1988; Simerly, R.L., Li, M., 2000; Gill, A. et al., 2009; Shah, 2012; Ahmed Sheikh, N., \& Wang, Z., 2013; Le, T.P.V. \& Phan, T.B.N., 2017; Nunes, P.J.M. et al., 2009) and return on equity - ROE (Chaklader, B. \& Chavla, D., 2016; Le, T.P.V. \& Phan, T.B.N., 2017; Gill, A. et al., 2009; Abor, 2005). Return on assets (ROA) is an indicator of how profitable a company is relative to its total assets. ROA gives a manager, investor, or analyst an idea as to how efficient a company's management is at using its assets to generate earnings. According to Bettis (1981, p. 384), ROA is widely used by managers and other stakeholders, and is in many cases highly correlated with other measurements such as ROE. Le and Phan (2017, p. 714) measured profitability, defined as performance, as ROE in their study on capital structure and its effect on firm performance. Return on equity (ROE) is a measure of financial performance calculated by dividing net income by shareholders' equity. Because shareholders' equity is equal to a company's assets minus its debt, ROE 
could be thought of as the return on net assets. Another important ratio of measuring profitability of the firms is EBITDA margin. EBITDA margin is an assessment of a firm's operating profitability as a percentage of its total revenue. Because EBITDA excludes interest, depreciation, amortization and taxes, EBITDA margin can provide an investor, business owner or financial professional with a clear view of a company's operating profitability and cash flow.

Our study is also well positioned within the theory of critical success factors. The theory of critical success factors is defined as "the limited number of areas in which results if they are satisfactory will ensure successful competitive performance for the organization" (Dinter, 2013). The concept of CSFs has been studied since the late 1970s (Lee, S., Ahn, H., 2008) and was first formally defined as the areas that a business should concentrate on to ensure competitiveness (Rockart, 1979). These may vary between industry sectors and even businesses (Hofer, C. W, \& Schendel, D., 1978; Trkman, 2010), implying that the use of specific CSFs to evaluate business success resided with managers of firms (Rockart, 1979). The definition of CSFs was later refined and broadened as, "those characteristics, conditions, or variables that when properly sustained, maintained, or managed can have a significant impact on the success of a firm competing in a particular industry" (Leidecker, J.K., Bruno, A.V., 1984, p. 24). Another definition of CSFs was given by Boynton and Zmud (1984) as "those few things that must go well to ensure success". However, the concept of "success" is elusive and, oftentimes, poorly defined (Trkman, 2010). Moreover, success is highly context-dependent, stemming from a unique combination of advantages. At the most fundamental level, success in business is equated with financial criteria like profitability and number of employees.

Critical success factors may change over time, consistent with the changes in the company and the environment. Relevant literature identifies a wide range of key success factors: product quality, costs, customer satisfaction, manufacturing flexibility, innovation, employee satisfaction and brand awareness (Eaton, 2005, p. 47). In order to better understand the factors that affect the performance of enterprise, the following components (Tadić, J., Boljević, A., 2015, str. 28-29; Hayes, R. \& Wheelwright, S., 1984; Foo, G., Friedman, D.J., 1992), will be analyzed:

- Quality. In addition to lower prices, customers demand higher quality products. On that basis, it can be said that quality is a critical element of revenue generation. Quality attributes include customer satisfaction (measured through the number of repeated purchases), the number of defective products per 1,000 units of product, consistency, and achievement of industrial standards. However, the concept of quality is much broader than the issues of products and services quality. It relates to the quality of all processes in the company, including the quality of key human resources - top management. Improvements in this area should contribute to a more efficient use of production resources, reducing the time required for production, reduce scrap, which will certainly have repercussions on the overall operating costs, cost of products, profitability and competitiveness of enterprise. It is the TQM concept, which is based on efforts to continuously improve quality and to deliver customers products and services of high quality on a consistent basis. 
- Flexibility. As a critical success factor, represents an internal power of company, which is reflected both in effective time management of the production process, as well as timely and accurate shipment. The importance of time is reflected in the speed of launch, timely deliveries to customers, as well as the ability of company to adapt to the changing environment in the short term. Time as a key factor for success is closely linked to the issue of quality of all business processes in the enterprise.

- Employees.An organization's success and profitability depends upon the performance of its employees. Business leaders know that a high-performing workforce is essential for the achievement of strategic business goals. The concept of employee engagement in the organizations is gaining importance. Employee engagement can be a deciding factor for an organization's success in today's competitive world. High levels of employee engagement promote retention of talent, foster a sense of belongingness, improve organizational performance and increase the stakeholder value. Engaged employees are attached to the organization, enthusiastic about their work and take efforts beyond the employment contract. Thus, engaged employees can be seen as powerful source of competitive advantage.

- Efficiency. As an essential component of business performance of each company, efficiency consists of two components: the costs and revenue. As determinants of cost, there are expenditures size, purchase price and the percentage of waste. Volume of production and sales price represents proposed indicators of revenue.

- Innovation. As an important component of the strategy of differentiation, the goal of innovation is to increase the number of new products, reduce development time of new products and the identification of new markets and customers. Hence, research and development $(\mathrm{R} \& \mathrm{D})$ represent one of the most important elements in the value chain. Indicators of this success factor are the time of launching a new product, the length of the development phase, the quick-change ability of product mix of the company. The most commonly used indicators of innovation are share of revenues from sales of new products in the total income, received awards etc.

\section{Methodology}

The aim of this study was to examine the relationship and influence of different critical success factors on profitability. For this purpose, we undertook an empirical study that included a sample of 200 companies in the food industry of the Republic of Serbia. The questionnaire survey was conducted in the period from October to December 2017. Within the group of critical factors, five independent variables are analyzed: quality, flexibility, employees, efficiency and innovation. Respondents rated the significance of critical factors on a scale of 1 to 100 , and the results were later divided with 100, for easier interpretation. Descriptive statistics of success factors is presented in Table 1. 
Table 1. Descriptive Statistics of success factors (drivers)

\begin{tabular}{|l|c|c|c|c|c|c|}
\hline & $\mathbf{N}$ & Min & Max & Mean & $\begin{array}{c}\text { Std. } \\
\text { Deviation }\end{array}$ & Variance \\
\hline Quality & 200 &, 12 &, 97 &, 538 &, 212 &, 045 \\
\hline Flexibility & 200 &, 14 &, 95 &, 485 &, 204 &, 042 \\
\hline Employees & 200 &, 11 &, 95 &, 476 &, 210 &, 044 \\
\hline Efficiency & 200 &, 18 & 1,00 &, 592 &, 214 &, 046 \\
\hline Innovation & 200 &, 12 &, 96 &, 482 &, 225 &, 051 \\
\hline
\end{tabular}

Source: Author's calculation

The highest mean value has efficiency $(0,592)$, with minimum and maximum values ranging from 0,18 to 1,00 . The smallest mean value has employees $(0,476)$, with minimum and maximum values ranging from 0,11 to 0,95 . This also mean that companies give the highest importance to efficiency and the smallest importance to employees as success factors. In order to determine the existence of linear dependence between the observed variables, the matrix of the scatter diagram was used. An equal distribution of points was determined. Thus, it can be concluded that linear dependence between critical factors does not exist. This, at the same time, means that critical factors can be used as regressors in the linear regression model.

One of the tasks in this study was related to the selection of indicators of profitability, with selected ROA (Return on Assets), ROE (Return on Equity) and EBITDA margin (Earnings Before Interest, Taxes, Depreciation and Amortization (EBITDA) divided by total revenue). The most important reason for choosing these indicators of profitability is that they are the ones most often used in foreign, but also in domestic business practice. Secondly, it is about yield indicators, and, as is known, investors are most interested in the yield on their investments. Within the group - profitability indicators, continuous dependent variables are displayed. Descriptive statistics of profitability indicators is presented in Table 2.

Table 2. Descriptive Statistics of profitability indicators

\begin{tabular}{|l|c|c|c|c|c|c|}
\hline & N & Min & Max & Mean & $\begin{array}{c}\text { Std. } \\
\text { Deviation }\end{array}$ & Variance \\
\hline ROA & 200 &,- 342 &, 474 &, 052 &, 140 &, 020 \\
\hline ROE & 200 &,- 321 &, 531 &, 084 &, 142 &, 020 \\
\hline $\begin{array}{l}\text { EBITDA } \\
\text { margin }\end{array}$ & 200 &,- 290 &, 593 &, 124 &, 145 &, 021 \\
\hline
\end{tabular}

Source: Author's calculation

ROA has a mean of 0,052 , with minimum and maximum values ranging from $-0,342$ to 0,474 . ROE has a mean of 0,084 , with minimum and maximum values ranging from $-0,21$ to 0,531 , while EBITDA margin has a mean of 0,124 , with minimum and maximum values ranging from $-0,290$ to 0,593 . Testing normality of distribution has been based on Kolmogorov-Smirnov and Shapiro-Wilkov test. The normality is shown to be statistically insignificant (accidental) deviation from the normality if the Sig. > 0.05 (Coakes, 2013, 
p. 46). In all three cases, the significance is greater than 0.05 , which shows that the assumption of the normal distribution is confirmed and can be accepted.

Starting from the basic subject and issues as well as the research goals of this paper, and taking into account recent scientific research on this topic, hypotheses that will be subject to testing are:

$H_{1}$ : There is significant correlation between assumed drivers - critical factors and profitability.

$\mathrm{H}_{2}$ : Assumed drivers - critical factors have a significant contribution to the prediction of profitability.

In accordance with the defined hypotheses, Pearson correlation coefficient ( $r$ ) and standard multiple regression analysis will be used. Statistical package SPSS IBM Statistics Version 21 will be used for the execution of selected statistical test.

\section{Results and discussion}

The relationship between critical factors and profitability, measured by indicators: ROA, ROE and EBITDA margin was investigated using the Pearson linear correlation coefficient (r) (Table 3.). Between the quality (as a critical factor) and profitability, measured using the ROA, ROE and EBITDA margin, a relatively poor positive correlation (Cohen, 1988, pp. 79-81) was calculated $(\mathrm{r}=0.215, \mathrm{r}=0.228, \mathrm{r}=0.235)$ $\mathrm{n}=200, \mathrm{p}<0.01$. It could be concluded that a low level of food quality and consumer satisfaction as a components of the success factor is followed by a low level of ROA, ROE and EBITDA margin. The quality explains 4.6\% variance of ROA, 5.1\% variance of ROE and 5.5\% variance of EBITDA margin. Between flexibility and profitability, a relatively poor positive correlation was calculated $(r=0,145, r=0,139, r=0,128) n=200$, $\mathrm{p}<0,05$, suggesting that untimely delivery and time extension of the production process as a components of the success factors is followed by a low level of ROA, ROE and EBITDA margin. The flexibility explains $2.1 \%$ variance of ROA, $1.9 \%$ variance of ROE and 1.6\% variance of EBITDA margin. Between employees and profitability, insignificant positive correlation was calculated $(r=0,027, r=0,030, r=0,025) n=200$, $\mathrm{p}>0,05$ (result is not statistical significant), suggesting that low level of employees satisfaction and training and development as a components of the success factors is followed by a low level of ROA, ROE and EBITDA margin. The employees explain $0.1 \%$ variance of ROA, $0.1 \%$ variance of $\mathrm{ROE}$ and $0.1 \%$ variance of EBITDA margin. Based on the study of the relationship between efficiency and profitability, the medium positive correlation was calculated $(r=0,498, r=0,490, r=476) n=200$, $\mathrm{p}<0,01$, suggesting that partially low levels of costs and partly high levels of income as a components of the success factor, follow a partially high ROA, ROE and EBITDA margin. The efficiency explains $24.8 \%$ variance of ROA, 24.0\% variance of ROE and $22.7 \%$ variance of EBITDA margin. Based on the study of the relationship between innovation and profitability, the medium positive correlation was calculated $(\mathrm{r}=0,349$, $\mathrm{r}=0,337, \mathrm{r}=0,322) \mathrm{n}=200, \mathrm{p}<0,01$, suggesting that partial investment in the research 
and development of new products and new technology as a components of the success factor, follow a partially high ROA, ROE and EBITDA margin. The innovation explains $12.2 \%$ variance of ROA, $11.4 \%$ variance of $\mathrm{ROE}$ and $10.4 \%$ variance of EBITDA margin.

Table 3. Correlation of critical factors with profitability indicators

\begin{tabular}{|c|c|c|c|c|}
\hline & & ROA & ROE & EBITDA margin \\
\hline \multirow{2}{*}{ Quality } & Pearson Correlation &, $215^{* *}$ & $228^{* *}$ &, $235^{* *}$ \\
\hline & Sig. (2-tailed) &, 002 & ,001 &, 001 \\
\hline \multirow{2}{*}{ Flexibility } & Pearson Correlation & $145^{*}$ &, 139 & $128^{*}$ \\
\hline & Sig. (2-tailed) & 040 &, 050 & 072 \\
\hline \multirow{2}{*}{ Employees } & Pearson Correlation &, 027 & 030 & 025 \\
\hline & Sig. (2-tailed) &, 708 & 668 &, 723 \\
\hline \multirow{2}{*}{ Efficiency } & Pearson Correlation & $498^{* *}$ & $490^{* *}$ & $476^{* *}$ \\
\hline & Sig. (2-tailed) &, 000 &, 000 &, 000 \\
\hline \multirow{2}{*}{ Innovation } & Pearson Correlation &, $349^{* *}$ & $337^{* *}$ &, $322^{* *}$ \\
\hline & Sig. (2-tailed) &, 000 &, 000 &, 000 \\
\hline \multicolumn{5}{|c|}{ **. Correlation is significant at the 0.01 level (2-tailed). } \\
\hline \multicolumn{5}{|c|}{ *. Correlation is significant at the 0.05 level (2-tailed). } \\
\hline
\end{tabular}

Source: Author's calculation

Excluding employees, as a critical factor, which is only slightly correlated with indicators of profitability, it can be concluded that is a Pearson correlation coefficient revealed a significant correlation with other critical factors and indicators of profitability. Therefore, between critical factors (except for employees) and profitability, a weak to medium strong positive correlation is calculated, and it can be concluded that the assumed hypothesis $\mathrm{H}_{1}$ is accepted, i.e.: There is significant correlation between assumed drivers - critical factors and profitability.

As defined in the research plan, second hypothesis testing is enabled by applying multiple regression analysis. Multiple regression analysis is conducted by taking 5 individual variables (quality, flexibility, employees, efficiency, innovation) as predictor variables, and indicators of profitability (ROA, ROE, EBITDA margin) as dependent variables. Predictor variables construct the model of regression and explain $43.1 \%$ variance of ROA, 42.0\% variance of ROE and 39.5\% variance of EBITDA margin, as the $\mathrm{R}^{2}$ value shows $0.431,0.420,0.395$ (Table 4.). The robustness of the model (Coakes, 2013, p. 163) is provided by the ANOVA table (Table 5.) with F value 31,198 and low $\mathrm{p}$ value 0,000 for ROA, F value 29,793 and low p valued for ROE, F value 27,023 and low $\mathrm{p}$ value 0,000 for EBITDA margin. The variance inflation factor (VIF) of five variables for each profitability indicator is less than the traditional thumb rule value of 10 (Cohen, J., Cohen, P., West, S.G., Aiken, L.S., 2003, p. 425; Cohen, 1988). 
Table 4. Model Summary ${ }^{\mathrm{b}}$

\begin{tabular}{|l|c|c|c|c|}
\hline & $\mathbf{R}$ & R Square & $\begin{array}{c}\text { Adjusted R } \\
\text { Square }\end{array}$ & $\begin{array}{c}\text { Std. Error of the } \\
\text { Estimate }\end{array}$ \\
\hline ROA &, $668^{\mathrm{a}}$ &, 446 &, 431 &, 106 \\
\hline ROE &, $659^{\mathrm{a}}$ &, 434 &, 420 &, 108 \\
\hline EBITDA margin &, $641^{\mathrm{a}}$ &, 411 &, 395 &, 113 \\
\hline \multicolumn{2}{|l}{} \\
\hline
\end{tabular}

Source: Author's calculation

Table 5. ANOVA ${ }^{\mathrm{a}}$

\begin{tabular}{|c|c|c|c|c|c|c|}
\hline \multicolumn{2}{|l|}{ Model } & $\begin{array}{c}\text { Sum of } \\
\text { Squares }\end{array}$ & df & $\begin{array}{c}\text { Mean } \\
\text { Square }\end{array}$ & $\mathbf{F}$ & Sig. \\
\hline \multirow{3}{*}{ ROA } & Regression & 1,739 & 5 &, 348 & 31,198 &, $000^{\mathrm{b}}$ \\
\hline & Residual & 2,163 & 194 & ,011 & & \\
\hline & Total & 3,902 & 199 & & & \\
\hline \multirow{3}{*}{ ROE } & Regression & 1,747 & 5 & ,349 & 29,793 &, $000^{\mathrm{b}}$ \\
\hline & Residual & 2,275 & 194 &, 012 & & \\
\hline & Total & 4,002 & 199 & & & \\
\hline \multirow{3}{*}{$\begin{array}{l}\text { EBITDA } \\
\text { margin }\end{array}$} & Regression & 1,739 & 5 & ,348 & 27,023 &, $000^{\mathrm{b}}$ \\
\hline & Residual & 2,496 & 194 &, 013 & & \\
\hline & Total & 4,235 & 199 & & & \\
\hline \multicolumn{7}{|c|}{ a. Dependent variable: ROA, ROE, EBITDA margin } \\
\hline \multicolumn{7}{|c|}{ b. Predictors: innovation, employees, quality, efficiency, flexibility } \\
\hline
\end{tabular}

Source: Author's calculation

Table 6. Coefficients of profitability indicators (ROA, ROE, EBITDA margin)

\begin{tabular}{|c|c|c|c|c|c|c|c|c|c|c|c|}
\hline \multirow{2}{*}{\multicolumn{2}{|c|}{ Model }} & \multirow{2}{*}{$\begin{array}{c}\begin{array}{c}\text { Standardized } \\
\text { Coefficients }\end{array} \\
\text { Beta }\end{array}$} & \multirow[t]{2}{*}{$\mathbf{t}$} & \multirow[t]{2}{*}{ Sig. } & \multicolumn{2}{|c|}{$\begin{array}{c}95.0 \% \\
\text { Confidence } \\
\text { Interval for B } \\
\end{array}$} & \multicolumn{3}{|c|}{ Correlations } & \multicolumn{2}{|c|}{$\begin{array}{l}\text { Collinearity } \\
\text { Statistics }\end{array}$} \\
\hline & & & & & $\begin{array}{l}\text { Lower } \\
\text { Bound }\end{array}$ & $\begin{array}{l}\text { Upper } \\
\text { Bound }\end{array}$ & $\begin{array}{l}\text { Zero- } \\
\text { order }\end{array}$ & Partial & Part & Tolerance & VIF \\
\hline \multirow{6}{*}{$\underset{ఝ}{\mathbb{1}}$} & (Constant) & & $-9,364$ & ,000 &,- 490 &,- 320 & & & & & \\
\hline & Quality & 251 & 4,682 & .000 & .096 & .235 & .215 & .319 & .250 & 994 & .006 \\
\hline & Flexibility & 207 & 3,842 & .000 & .069 & .215 &, 145 & .266 & .205 & 981 & .019 \\
\hline & Employee & 030 & .552 & .581 &,- 051 & .090 & .027 &, 040 & .030 & 988 &, 013 \\
\hline & Efficiency & 485 & 9,032 & .000 & .247 & 385 & .498 & .544 & .483 & 992 & .008 \\
\hline & Innovation & 342 & 6,351 & .000 &, 147 & .279 & .349 & .415 & .339 & 983 & .018 \\
\hline \multirow{6}{*}{ 뒁 } & (Constant) & & $-8,502$ &, 000 &,- 465 &,- 290 & & & & & \\
\hline & Quality & 263 & 4,856 & .000 & .105 & .248 & 228 & .329 & .262 & 994 & .006 \\
\hline & Flexibility & 200 & 3,678 & .000 & .065 & .214 & .139 & .255 & .199 & 981 & 019 \\
\hline & Employee & 034 & ,624 & .533 &,- 049 & .095 &, 030 &, 045 & .034 & 988 & 013 \\
\hline & Efficiency & 478 & 8,814 & .000 & .245 & .387 & 490 & .535 & 476 & .992 & .008 \\
\hline & Innovation & 331 & 6,068 & .000 &, 141 & .276 & .337 & .399 & .328 & 983 & .018 \\
\hline \multirow{6}{*}{ 突 } & (Constant) & & $-7,200$ &, 000 &,- 426 &,- 243 & & & & & \\
\hline & Quality & 269 & 4,857 & .000 & .110 & .259 & 235 & .329 & .268 & 994 &, 006 \\
\hline & Flexibility & 187 & 3,366 & .001 &, 055 & .212 & .128 & .235 & 186 & 981 & 019 \\
\hline & Employee & .028 & .512 & .610 &,- 056 & .095 & .025 & .037 & .028 & 988 &, 013 \\
\hline & Efficiency & 464 & 8,382 & .000 & .241 & .389 & 476 & .516 & 462 & 992 & .008 \\
\hline & Innovation & 317 & 5,697 & .000 & .134 & .276 & .322 & 379 & 314 & 983 &, 018 \\
\hline
\end{tabular}

Source: Author's calculation 
To compare the contribution of all independent variables, coefficients Beta will be used. In this case, the highest coefficient of beta has the efficiency $(0.485,0.478,0.464)$, which means that the efficiency individually contributes most to the explanation of the dependent variable ROA, ROE and EBITDA margin, after deducing the variance explained by the other variable in the model. The company, which for 10 points increase the importance of the efficiency, on average, will increase ROA by $4.85 \%$, ROE by $4.78 \%$ and EBITDA margin by $4.64 \%$.

After efficiency, the following beta coefficients are for innovation $(0.342 ; 0.331$; $0.317)$, quality $(0.251 ; 0.263 ; 0.269)$, flexibility $(0.207 ; 0.200 ; 0.178)$ and employees $(0.030 ; 0.034 ; 0.028)$. Since the significance of the first four factors is less than 0.05 , it can be concluded that efficiency, innovation, quality and flexibility give a significant unique contribution to the prediction of the dependent variable ROA, ROE and EBITDA margin. The variable employees do not give a significant unique contribution to the prediction of the dependent variable ROA, ROE, EBITDA margin. Contrary to expectation, employees, as critical success factor were not found to have any significant effect on non-financial performance and financial performance in research of Lo and group of associates (2016, p. 383).

With multiple regression analyses were explored how well five different critical factors (quality, flexibility, employees, efficiency, innovation) predict the profitability, measured by ROA, ROE and EBITDA margin. Preliminary examination verified the assumptions of normality, linearity, atypical points, homogeneity of variance, independence of residuals, multicollinearity and singularity (Green, M., Salking, N., 2014 , p. 238). Violation of assumptions are not been noted. On the basis of determining the strength of the impact of the assumed critical factors (quality, flexibility, employees, efficiency, innovation) on profitability, it can be concluded that efficiency, innovation, quality and flexibility have a significant impact on predicting profitability indicators: $\operatorname{ROAF}(5,194)=31,198, \mathrm{p}<0,05 ; \operatorname{ROE} \mathrm{F}(5,194)=29,793, \mathrm{p}<0,05 ;$ EBITDA margin $\mathrm{F}(5,194)=29,793, \mathrm{p}<0,05$. Employees as a critical factor, on the other hand, are not a significant predictor of profitability indicators: ROA, ROE, EBITDA margin. Given that four of the five variables make a significant contribution to the prediction of dependent variables, i.e. profitability indicators, it can be concluded that the assumed hypothesis $\mathrm{H}_{2}$ is accepted: Assumed drivers - critical factors have a significant contribution to the prediction of profitability.

\section{Conclusions}

This paper considers the relationship and contribution of critical success factors as the drivers for achieving profitability as one of the organizational performance in food industry of Serbia. This study can help managers in food industry to identify critical success factors, with which they can add most value to their business. In any organization, the most difficult and complex tasks are to facilitate decision-making at various levels and smooth functioning of management processes in order to achieve desired goals. The application of CSF theory helps in reducing this complexity. It 
enables the organization to focus on the most important CSFs that lead to the successful achievement of their desired goals (Bai, C., Sarkis, J., 2013). The theory of CSF also acts as a tool for measuring the performance of an organization towards attaining their goals (Shankar, R., Gupta, R., Pathak, D.K., 2018, p. 207).

Contribution of the paper lies in the analysis of the issues that are crucial to the success of companies, and in establishing a set of critical success factors that determinable affect to the achievement of company performance. By comparing several critical success factors in a model, this study revealed the most significant critical success factors that can contribute to better organizational performance. Hence, this study has successfully developed some guidelines for scholars who are interested in this field to further test the relationships among these constructs and contribution of critical success factors to profitability.

The findings of this study suggest that, for the context of food industry in Serbia, efficiency, innovation, quality and flexibility as CSFs are positively related to profitability indicators: ROA, ROE, EBITDA margin. However, the results do not support any relationship between employees and profitability indicators. Efficiency and innovation are the most important factors for companies to improve their profitability, and therefore companies should prioritize their investments in these success factors.

\section{Conflict of interests}

The authors declare no conflict of interest.

\section{Reference}

1. Abor, J. (2005). The effect of capital structure on profitability: an empirical analysis of listed firms in Ghana. The Journal of Risk Finance , 6(5), 438-445.

2. Ahmed Sheikh, N., \& Wang, Z. (2013). The impact of capital structure on performance. International Journal of Commerce and Management, 23(4), 354368.

3. Alias, Z., Zawawi, E.M.A., Yusof, K., Aris, N.M. (2014). Determining Critical Success Factors of Project Management. Procedia - Social and Behavioral Science, 153(16), 61-69.

4. Bai, C., Sarkis, J. (2013). A grey-based DEMATEL model for evaluating business process management critical success factors. International Journal of Production Economics, 146, 281-292.

5. Barton, S.L., Gordon, P.J. (1988). Corporate Strategy and Capital Structure. Strategic Management Journal, 9(6), 623-632.

6. Bettis, R. (1981). Performance Differences in Related and Unrelated Diversified Firms. Strategic Management Journal, 2(4), 379-393.

7. Boynton, A.C., Zmud, R.W. (1984). An assessment of critical success factors. Sloan Management Review, 25(3), 17-27. 
8. Chaklader, B. \& Chavla, D. (2016). A Study of Determinants of Capital Structure through Panel Data Analysis of Firms Listed in NSE CNX 500. Vision:The Journal of Business Perspective, 20(4), 267-277.

9. Coakes, S. (2013). SPSS 20.0 for Windows: Analysis without anguish. New Jersey: Wiley Publishin, Inc.

10. Cohen, J. (1988). Statistical power analysis for the behavioral science. Hillsdale, New York: Lawrence Erlbaum Associates.

11. Cohen, J., Cohen, P., West, S.G., Aiken, L.S. (2003). Applied Multiple Regression/ Correlation Analysis for the Behavioral Sciences (3 ed.). New Jersey: Lawrence Erlbaum Associates.

12. Dinter, B. (2013). Success factors for information logistics strategy - an empirical investigation. Decision Support Systems, 54(3), 1207-1218.

13. Foo, G., Friedman, D.J. (1992). Variability and Capability: The Foundation of Competitive Operations Performance. AT\&T; Technical Journal, July/August, 2-9.

14. Gill, A., Biger, N., Pai, C., Bhutani, S. (2009). The Determinants of Capital Structure in the Service Industry: Evidence from United States. The Open Business Journal, 2(1), 48-53.

15. Green, M., Salking, N. (2014). Using SPSS for Windows and Macintosh: Analyzing and Understanding Data. New York: Pearson Education, Inc.

16. Hayes, R. \& Wheelwright, S. (1984). Restoring Our Competitive Edge: Competing Through Manufacturing. New York: John Wiley.

17. Hofer, C. W, \& Schendel, D. (1978). Strategy formulation: analytical concepts. Saint Paul: West Publishing co.

18. Kimmel, P., Weygandt, J., Kieso, D. (2012). Financial Accounting. New Jersey: John Wiley.

19. Kotula, M., Ho, W., Kumar Dey, P., Lee, C.K.M. (2015). Strategic sourcing supplier selection misalignment with critical success factors: Findings from multiple case studies in Germany and the United Kingdom. International Journal of Production Economics, 166, 238-247.

20. Le, T.P.V. \& Phan, T.B.N. (2017). Capital structure and firm performance: Empirical evidence from a small transition country`. Research in International Business and Finance, 42, 710-726.

21. Lee, S., Ahn, H. (2008). Assessment of process improvement from organizational change. International Journal of Information Management, 45(5), 270-280.

22. Leidecker, J.K., Bruno, A.V. (1984). Identifying and using critical success factors. Long Range Planning, 17(1), 23-32.

23. Lo, C.M., Wang, C.W., Wah, C.R.J., Ramayah, T. (2016). The critical success factors for organizational performance of SMEs in Malaysia: a partial least squares approach. Review of Business Management, 18(61), 370-391.

24. Nunes, P. J. M., Serrasqueiro, Z. M. \& Sequeira, T. N. (2009). Profitability in Portuguese service industries: a panel data approach. The Service Industries Journal, 29(5), 693-707. 
25. Pervan, M., Mlikota, M. (2013). What determines the profitability of companies: case of croatian food and beverage industry. EKONOMSKA ISTRAŽIVANjAECONOMIC RESERACH, 26(1), 277-286.

26. Rockart, J. (1979). Chief executives define their own data needs. Harvard Business Review, 57(2), 81-93.

27. Shah, S. (2012). Determinants of capital structure of leasing companies in Pakistan. Applied Financial Economics, 22(22), 1841-1853.

28. Shankar, R., Gupta, R., Pathak, D.K. (2018). Modeling critical success factors of traceability for food logistics system. Transportation Research Part E, 119, 205222.

29. Simerly, R.L., Li, M. (2000). Environmental Dynamism, Capital Structure and Performance: A Theoretical Integration and an Empirical Test. Strategic Management Journal, 21(1), 31-49.

30. Statistical Office of the Republic of Serbia. (2018). Statistical Yearbook. Belgrade: Statistical Office of the Republic of Serbia.

31. Tadić, J., Boljević, A. (2015). Integration of Critical Success Factors in Order to Improve Performance of the Company. Strategic Management, 20(1), 26-33.

32. Trkman, P. (2010). The critical success factors of business process management. International Journal of Information Management, 30(2), 125-134.

33. Vuković, B., Jakšić, D. (2019). The effect of working capital management on profitability: evidence from southeast europe. Economics of Agriculture -, 66(1), 159-172. 